\title{
Global speech and global terrorism: a tall tale of two cities
}

\author{
Clive Walker
}

\author{
Professor of Criminal Justice Studies, University of Leeds*
}

\section{Introduction}

7 he propositions that "libel tourism" exists and that it constitutes a pernicious threat to 1 free speech interests have gained wide currency. A somewhat partisan (American) definition of libel tourism is rendered as follows: ${ }^{1}$

What is "libel tourism"? The phrase refers to international forum shopping. The libel tourist is a plaintiff who files a libel action in a forum with laws favorable to the libel plaintiff. The libel tourist's target is often an American author or publisher. Accordingly, the libel tourist is ordinarily attempting to circumvent the First Amendment by suing the American speaker in a foreign court.

Given this slant, the mischief is one for which the jurisdiction of England and Wales lies accused of contributing more prominently than any other, though there are certainly supplementary national offenders, ${ }^{2}$ especially if "group libels" are considered. ${ }^{3}$ Thus, London has been denigrated as the "libel capital" of the world, with laws which are "uniquely stacked in favour" of foreign libel plaintiffs. ${ }^{4}$ Its stance is often contrasted sharply with the dismissive treatment of such plaints in New York and other US cities.

The point of this paper is to suggest that these first impressions may be misleading and that this "tale of two cities", London versus New York, does not exactly tessellate with the Manichean divide which is thereby mounted between speech repression and speech freedom. The contrast becomes especially dimmed when the focus is turned to speech about terrorism, which has frequently been a trigger for libel tourism. Accordingly, this "tale" will be told in three parts. Part 1 will consider why many of the key libel cases at the

* The author thanks the organisers and participants for comments, especially Dr David Capper, Professor David Partlett and Professor Russ Weaver.

1 R L McFarland, "Please do not publish this article in England: a jurisdictional response to libel tourism" (2010) 79 Mississippi Law Journal 617, p. 625.

2 Criticism has also been levelled against Australia (Dow Jones v Gutnick [2002] HCA 56; Evony v Everiss, www.guardian.co.uk/technology/2010/mar/31/evony-libel-case-bruce-everiss) and Canada (Black v Breeden 2010 ONCA 547 (Ont. C.A.)).

3 See Yahoo! Inc. v La Ligue Contre Le Racisme et L'Antisemitisme 169 FSupp2d 1181 (ND Cal 2001), reversed for lack of personal jurisdiction, 379 F3d 1126 (9th Cir 2004), reversed and remanded to district court to dismiss without prejudice, 433 F3d 1199 (9th Cir 2006 en banc).

4 "Be reasonable", The Times, 19 May 2005, p. 19. See also for the use of English libel law by US celebrities, R Verkaik, "Invasion of the libel tourists", The Independent, 21 August 2008, p. 8. 
heart of libel tourism have arisen from terrorism-related speech. It will be necessary to reflect upon why late modernity engenders speech about terrorism across borders. Part 2 tackles the recent practice of libel tourism itself, as related to the paradigm case of allegations about involvement in terrorism. It explains the relevant English libel law litigation, based in London, and the US reactions to it, initially hatched in New York. Part 3 suggests why this apparently contrasting tale of two cities might be a "tall tale". The paper does not deny the different approaches and outcomes in libel laws in the respective jurisdictions. Rather, its point is to set those differences in the wider context of the legal treatment of speech about terrorism. If one considers public law rights to speech about the state as well as private law rights to speech about persons, a more balanced picture emerges. In that light, US reactions to speech about terrorism and the restrictions imposed are in some ways more threatening than those on the other side of the Atlantic.

\section{Part 1: A sense of place}

The first part of the tale of two cities requires a comprehension of the globalised nature of networked terrorism and the ways in which it engenders globalised speech. The purpose is to understand why so many of the libel tourism cases relate to terrorism.

The late modern "third millennium" variant of terrorism is characterised by heterarchical and sometimes self-generating networks whose objectives are focused on broader goals than the narrow nationalism or ethnicity pursued by most terrorist groups during the previous century. The qualitatively distinct features of contemporary terrorism include religious and cultural motivations and the cataclysmic use of suicide attacks associated with millenarian language, alongside predominantly late-modernist structures and communications. ${ }^{5}$ The same features apply to participation in such terrorism - the participants may be not be so localised in ethnicity, residence, or political objectives as in previous terrorism campaigns, though this trend does not rule out an important role for locals who endorse the globalised cause and thereby inflict "neighbour terrorism". ${ }^{6}$ These emergent features can be detected in the paradigm case of third millennium terrorism as represented by Al-Qaida. Its very title embodies the notion of the "base" of a network, but, increasingly, that base is more metaphysical than physical, functioning as a foundation for inspiring ideological jihad rather than offering the practicalities of training or shelter for mijabideen. ${ }^{7}$ This trend is partly a result of external pressures, especially the military invasion of Afghanistan in 2001, which eliminated any sustained concentration of adherents. Predator missiles now ensure that physical gatherings almost anywhere entail high risks for Al-Qaida operatives, whether in Afghanistan, Pakistan, or countries even further afield such as in Yemen. ${ }^{8}$

This spread of third millennium terrorism and terrorism ideology through networks and across jurisdictions entails a number of important implications for communications systems and the laws which govern them, including libel laws. First, the maintenance of coherence

5 See R. Gunaratne, Inside al Qaeda (New York: Columbia UP 2002); J Gray, Al Qaeda and What it Means to be Modern (London: Faber and Faber 2003); M Sageman, Understanding Terror Networks (Pennsylvania: University of Pennsylvania Press 2004); B Lia, Globalisation and the Future of Terrorism (London: Routledge 2005); P Neumann, Old and New Terrorism (Cambridge: Polity 2009); E N Kurtulus, "The 'new terrorism' and its critics" (2011) 34 Studies in Conflict \& Terrorism 476.

6 See C Walker, “Know thine enemy as thyself': discerning friend from foe under anti-terrorism laws” (2008) 32 Melbourne Law Review 275.

7 D Rashwan, "After Mombassa", Al-Abram Weekly Online (No 619), 2-8 January 2003, http://weekly.ahram.org.eg/2003/619/op13.htm.

8 See D Kretzmer, "Targeted killing of suspected terrorists" (2005) 16 European Journal of International Law 171; E Gross, The Struggle of Democracy against Terrorism (Charlottesville: University of Virginia Press 2006), ch. 8; J Murphy and A J Radsan, "Due process and the targeted killing of terrorists" (2009) 32 Cardozo Law Review 405. 
of strategy by terrorist movements demands some unifying messages and headlines, lest the objectives of individual cells become so diffuse as to be unintelligible. Some of this media work is provided by the terrorism movement itself. In the case of Al-Qaida, a notable development has been the issuance of regular bulletins of the Inspire magazine. ${ }^{9}$ This publication is an English language online-only magazine of "open source jihad" which is said to be produced by Al-Qaida in the Arabian Peninsula (AQAP). Yet, no matter how glossy the cover, such a magazine is not able to engage a wide audience, and so terrorism must force itself on the public as an issue which cannot be ignored in the mainstream media. This outcome, which forms the expressive aspect of many terrorist attacks, ${ }^{10}$ was achieved par excellence by Al-Qaida on 9/11 with its strike against the "Far Enemy" and a prime symbol of Western globalisation. ${ }^{11}$ Since then, the activities and threats of affiliates have been unfailingly able to occupy the headlines almost at will.

The resultant media coverage of Al-Qaida is neither evenly spread in geographical terms, nor is it bipolar between terrorists and the state. In terms of geographical spread, there are reasons for London and New York - the two cities at the heart of this tale - to be chief nodal points for speech about terrorism. In the case of New York, the two attacks on the World Trade Center (1993 and 2001) have inevitably heightened local media interest in terrorism. As for London, the experience of multiple IRA (Irish Republican Army) attacks through to the bombings on $7 / 7$ also concentrates attention. There also comes into play the additional factor that many Arabic media organisations are represented in London, bolstered by large Middle Eastern émigré or visiting audiences. These Arab-centric media outlets are seemingly more welcome and tolerated in London than in New York, where the cable transmission of Al Manar has been deemed to amount to the offence of material support for terrorism. ${ }^{12}$ Further evidence of the US administration's attitude to Arab media outlets include its alleged plans to bomb the offices of Al-Jazeera in Doha. ${ }^{13}$

In terms of bipolarity between terrorists and state, both the US and UK governments are keen to present to the public their own discourses about terrorism, whether in the form of counter-strategies ${ }^{14}$ or counter-narratives. ${ }^{15}$ Yet, communications about terrorism are not confined to a bipolar discourse between terrorists and the state. In reality, there is a profusion of independent expressions, as should always be the position in a healthy open society.

The late-modern features of terrorism, already described, here interplay with the importance and amount of media coverage of terrorism. A publication about late-modern terrorism is as likely to concern foreigners as citizens. It is as likely to emanate from a

9 A Fordham, “Terror magazine's tip: make a bomb in mom's kitchen”, The Times, 2 July 2010, p. 45.

10 See B L Nacos, Mass-Mediated Terrorism (Lanham: Rowan \& Littlefield 2002); P Norris, M Kern and M Just, Framing Terrorism (London: Routledge 2003); D L Altheide, Terrorism and the Politics of Fear (Lanham: AltaMira Press 2006).

11 F A Gerges, The Far Enemy (New York: Cambridge UP 2005).

12 US v Iqbal (USDC SDNY) reported in New York Times, 24 April 2009, p. A22.

13 "Bush plot to bomb his Arab ally", Daily Mirror, 22 November 2005, p. 1. David Keogh and Leo O’Connor were convicted of offences under the Official Secrets Act 1989 for the unauthorised disclosure of this information: In re Times Newspapers Ltd [2007] EWCA Crim 1925.

14 For the UK, see Home Office, Countering International Terrorism Cm 6888 (London: TSO 2006), as developed by Cm 7547 (London: TSO 2009), Cm 7833 (London: TSO 2010), and Cm 8123 (London: TSO 2011); Cabinet Office, The National Security Strategy of the United Kingdom Cm 7291 (London: TSO 2008). For the US, see US President, National Strategy for Combating Terrorism (Washington DC 2006 and 2011).

15 For the UK, see Report of the Official Account of the Bombings in London on 7 July 2005 HC 1087(2005-2006 ). For the US, see National Commission on Terrorist Attacks upon the United States, The $9 / 11$ Commission Report (Washington DC: GPO 2004). 
foreign-based publication, albeit that it commands the attention of just a minor and specialist readership in London or New York, as to be the handiwork of an indigenous media source aimed at the mass native population. Yet, it is at this point of publication about late-modern terrorism that a divergent tale of two cities arises. Though London and New York share many features in respect of their abiding interests in terrorism and also their heavy concentrations of media activity, there is apparent divergence over how the law of libel applies in each location to expressions about terrorism. That divergence will next be considered in Part 2.

\section{Part 2: Libel laws unbounded and libel laws confounded}

There are important differences in the ways in which libel laws apply to expression about terrorism in London and New York.

\section{LONDON LIBEL ACTIONS}

In London, there is encouragement towards "late-modern" applications of libel, in other words, a willingness to treat national jurisdictional boundaries as relatively fluid. ${ }^{16}$ The impugning of foreign reputations and the invasion of foreign publications present no elemental obstacles to this highly networked legal node. Therefore, a combination of relatively lax rules about forum and damage ${ }^{17}$ all favour the business of claimants with limited nexus to the jurisdiction. In addition, the rules as to onus ${ }^{18}$ are also encouraging given that the subject matter of the expression, in this context regarding terrorism, engages national security interests which will normally hamper exacting evidence-gathering by a defendant. As a result, the impact of the Reynolds (or public interest) defence may be somewhat neutered. ${ }^{19}$

The outcome of these features is that there has been a constant stream of litigation assailing the London courts based on libels about connections to terrorism. The claimants are often (but not exclusively) wealthy Arabs. The defendants have been mainly mass media corporations, but individuals are also affected. In either case, they may be UKbased or foreign. The more significant disputes regarding third millennium terrorism include the following. ${ }^{20}$

The cause célèbre is Rachel Ehrenfeld, a US citizen based in New York and the author of Funding Evil. ${ }^{21}$ In this book, she alleged that Khalid bin Mahfouz, a Saudi Arabian businessman and former head of a Saudi Arabian bank, had provided finance to Al-Qaida and other terror groups. The US publisher mainly marketed the book in the US, but at least 23 copies were dispatched to the UK via internet sales. In addition, one chapter was accessible from the ABCNews.com website, which was also viewable in the UK. A default judgment of libel was sustained in the English High Court, which awarded damages under the Defamation Act 1996 summary scheme (amounting to $£ 10,000$ each for

16 See M Castells, The Information Age vol. I: The rise of network society (Oxford: Blackwell 1996); The Information Age vol. II: The power of identity (Oxford: Blackwell 1997); The Information Age vol. III: End of millennium (Oxford: Blackwell 1998).

17 For details, see W V H Rogers and P Milmo, Gatley on Libel and Slander 11th edn (London: Sweet \& Maxwell 2008), paras 26.20, 26.31, 34.50; T Hartley, "Libel tourism and conflict of law" (2010) 59 ICLQ 25.

18 See Reynolds v Times Newspapers Ltd [2001] 2 AC 127 at 203; Rogers and Milmo, Gatley, n. 17 above, paras. 11.3, 25.19 .

19 [2001] 2 AC 127. See further Jameel v Wall St Journal Europe SPRL [2006] UKHL 44. For a full survey, see Rogers and Milmo, Gatley, n. 17 above, ch. 15.

20 See, generally, R Balin, L Handman and E Reid, "Libel tourism and the Duke's manservant - an American perspective" [2009] European Human Rights Law Review 303.

21 Chicago: Bonus Books 2003. 
Mahfouz and his two sons), ${ }^{22}$ enjoined her from further publication of the defamation in England and Wales, and ordered her to publish an apology under the Defamation Act 1996. ${ }^{23}$ Mafouz took no steps to enforce the judgment either in London or in New York up to his death in $2009 .^{24}$

A very similar action was lodged by Mahfouz in 2007 against the American academic authors, $\mathrm{J}$ Millard Burr and Robert $\mathrm{O}$ Collins, in respect of their book, Alms For Jihad, ${ }^{25}$ which again linked Mahfouz to terrorism funding. Cambridge University Press decided to withdraw the book and not to defend the action. Allegedly contrary to the wishes of the authors, Cambridge University Press apologised, asked libraries to remove the book from public access, and paid undisclosed damages and costs. ${ }^{26}$

There next appeared some equally prominent claimants in Jameel v Wall Street Journal. ${ }^{27}$ The action involved a claim by a billionaire Saudi car distributor, Mohammed Jameel, arising from a press report that bank accounts associated with several Saudi citizens, including Jameel's family and his businesses, had been monitored by Saudi authorities on the request of US investigators for alleged terrorist ties. The trial judge, Eady J, ruled that publication of the story was not in the public interest, inter alia, because it breached an agreement between the US and Saudi governments to keep the monitoring processes secret. Eady J also rejected the defendant's argument that the claimant should prove special damage. An award of $f, 40,000$ damages was made. The Court of Appeal rejected the Reynolds defence on grounds that the defendant had not undertaken responsible journalism because of inadequate verification efforts. ${ }^{28}$ It also confirmed that there was no need for a claimant to prove special damage even in the case of a foreign corporation. ${ }^{29}$ The House of Lords confirmed that a presumption of damage applied to a trading company. But the Court of Appeal award to the claimant was reversed by the House of Lords. The lead speech of Lord Hoffmann ruled that the media met the Reynolds tests: ${ }^{30}$

It is for the judge to apply the test of public interest. But this publication can easily pass that test. The thrust of the article as a whole was to inform the public that the Saudis were co-operating with the US Treasury and monitoring accounts. It was a serious contribution in measured tone to a subject of very considerable importance.

In the further view of Lord Scott:

It is no part of the duty of the press to co-operate with any government, let alone foreign governments, whether friendly or not, in order to keep from the public information of public interest the disclosure of which cannot be said to be damaging to national interests. ${ }^{31}$

22 See Defamation Act 1996, s. 8(3).

23 Mabfouz v Ehrenfeld [2005] EWHC 1156 (QB). See also Mahfouz v Brisard [2006] EWHC 1191 (QB).

24 See "Writ large. Are English courts stifling free speech around the world?", The Economist, 8 January 2009, www.economist.com/world/international/displaystory.cfm?story_id=12903058.

25 Cambridge: CUP, 2006. See now http://defendingfreespeech.files.wordpress.com/2010/02/alms_for_jihadfinal.pdf.

26 See T Tivnan, “CUP pays damages to Saudi sheikh", The Bookseller, 3 August 2007, www.thebookseller.com/news/cup-pays-damages-saudi-sheikh.html.

27 [2005] EWCA Civ 74; [2006] UKHL 44. See also Jameel v Times Newspapers Ltd [2004] EWCA Civ 983; Jameel v Dow Jones [2005] EWCA Civ 75. Compare Al Rajbi Banking and Investment Corp. v Wall Street Journal Europe SPRL [2003] EWHC 1358 QBD. See Rogers and Milmo, Gatley, n. 17 above, para. 15.5.

28 [2005] EWCA Civ 74 paras 88, 89.

29 [2005] EWCA Civ 74 para.113.

30 [2006] UKHL 44 para.49.

31 [2006] UKHL 44 para.142. 
There were mixed messages for libel tourism over terrorism matters arising from this case. On the one hand, foreign corporate interests are as readily protected as individual reputations, perhaps an unsurprising result in a globalised trading post like London. ${ }^{32}$ On the other hand, while the libel suit can be heard, its success is by no means assured and expressive rights are taken into account through the Reynolds defence so long as there is evidence of responsible journalism.

Next, in Ghannouchi v Al Arabiya, 33 a Dubai-based television broadcaster was sued by the claimant, a Tunisian political exile who had been granted asylum in 1993 and was the leader of the exiled An Nahda party, for a programme in which he was alleged to be an extremist with links to Al-Qaida. The defendant argued that the (Arab language) publication in England and Wales was minimal and did not defend the action. Eady J awarded $£ 165,000$.

The foregoing list, by no means exhaustive, ${ }^{34}$ is weighty and contrasts with a more modest list which arose from decades of Irish Republican terrorism during which time libel tourism was not an issue. ${ }^{35}$ One important and instructive case from that era might, however, be mentioned. In Monteith v Clarke, Neill, 36 Channel Four TV had broadcast in 1991 a programme, The Committee, made by the independent Box Productions Ltd in which it was claimed that there was a secret and unofficial Ulster Central Co-ordinating Committee. This committee involved collusion between Loyalist businessmen, politicians, police and paramilitaries and pursued a programme of assassinations of Republican targets. The Royal Ulster Constabulary investigated these allegations, and, though Box Productions refused to reveal all its sources, ${ }^{37}$ the police issued a detailed press release that the allegations were an invention. Much reliance was placed on evidence obtained from an unnamed Loyalist who had made a statement to the police that the allegations had been fed to the reporters in Box Productions in order to discredit the police in the minds of the Nationalist community. The statement had been made in the presence of a solicitor, identified as the applicant, Richard Monteith. The chief executive of Box Productions, the fourth respondent, then sought to refute the doubts cast on the veracity of his programme. In statements published by the Sunday Times and the BBC, he downplayed the importance of the police's witness and claimed that the applicant was himself a member of the alleged committee. The applicant sought leave to bring a prosecution for criminal libel against the Sunday Times journalist who interviewed the chief executive of Box Productions, the editor of the Sunday Times, the proprietor of the Sunday Times and the chief executive of Box Productions for both the press and television interviews. Carswell J concluded that three of

32 In Australia, there are limits on corporate libel suits where the corporate objects do not include financial gain or where it employs fewer than 10 persons: Civil Law (Wrongs) Act 2002 (ACT) s. 121; Defamation Act 2005 (NSW, Qld, SA, Tas, Vic, WA) s. 9; Defamation Act 2006 (NT) s. 8. But corporate rights have been maintained in the Irish Defamation Act 2009, s. 12.

338 November 2007 (reported in Rogers and Milmo, Gatley, n. 17 above, A3.31). See also Ghannouchi v Houni Ltd and Others [2003] EWHC $552(\mathrm{QB})$.

34 See also Hewitt v Grunwald [2004] EWHC 2959 (QB): the website of the Board of Deputies of British Jews published statements that the charity Interpal was involved in the support of terrorism through donations to Hamas; the case was settled with an apology: http://news.bbc.co.uk/1/hi/uk/4564784.stm); Veliu v Marrekaj [2006] EWHC 1710 (QB): a claim by a journalist based in the UK in respect of an article in an Albanian language newspaper published in the jurisdiction that alleged that he had been implicated in the London terrorist bombings; an apology and substantial damages were the remedies; Burstein $\mathrm{v}$ Associated Newspapers Ltd (summary judgment to the defendant on the basis that the words in an opera review that the author admired terrorism were mere comment) [2007] EWCA Civ 600.

35 See e.g. Doherty and Others v Telegraph Group Ltd (Kerr J, 12 September 2000); Madden v Sunday Newspapers [2006] NIQB 1; Curistan v Times Newspapers [2007] EWHC 926, [2008] EWCA Civ 432.

36 (1993) QBD, LEXIS. The dispute concluded with a settlement in damages for the plaintiff.

37 The refusal resulted in a heavy fine for contempt: DPP v Channel 4 \& Box Productions, The Times, 14 September 1992. 
these applications were misconceived and had to be dismissed. Reviewing the legislative history, the judge held that:

It seems to me clear that the words "person responsible for the publication of a newspaper" in s. 8 of the Law of Libel (Amendment) Act 1888 are to be construed ejusdem generis with the preceding words "any proprietor, publisher, editor". In my view they are intended to cover the persons who bring the newspaper out, not the contributors whose material is contained in the issues published.

It followed that leave for a criminal libel prosecution was required neither against the first respondent, the reporting journalist, nor against the fourth respondent, the source of the story. It was further concluded in respect of the latter that the statements made on television additionally fell outwith s. 8 since:

[T] he word "newspaper" is by section 1 of the Law of Libel (Amendment) Act 1888 to have the same meaning as in the Newspaper Libel and Registration Act 1881. That definition, contained in section 1 of the 1881 Act, has never been amended to include television or radio broadcasts.

The remaining application for leave against the editor and the proprietors of the Sunday Times did properly fall within s. 8, but leave was refused on the facts. Whilst the criminal libel threat thus fell away, no attempt was made to publish in the UK the book on which the programme had been based, though it remains available in the US. ${ }^{38}$ Criticisms of the author, Sean McPhilemy, were themselves the subject of a successful (for the claimant) libel action. 39

\section{NEW YORK COUNTER-LIBEL ACTIVITIES}

In contrast to the London experience, New York libel actions in response to expressions about terrorism will often be confounded by the US Constitution's First Amendment, as applied by the judgment in New York. Times $\mathrm{v}$ Sullivan. ${ }^{40}$ A good example of the variant experience concerns Hamas: Politics, charity, and terrorism in the service of jihad, a book by Professor Matthew Levitt and published by Yale University Press, in which Hamas is presented as an organisation organically linked to terrorism. ${ }^{41}$ A libel suit begun in California was dropped in 2007. The libel suit was filed on behalf of KinderUSA, a proPalestinian group, especially because of the statement that, " $[\mathrm{t}]$ he formation of KinderUSA highlights an increasingly common trend: banned charities continuing to operate by incorporating under new names in response to designation as terrorist entities or in an effort to evade attention. This trend is also seen with groups raising money for Al-Qaida." After indications of a vigorous defence by the publisher, the suit was withdrawn.

Furthermore, the prospect of silencing abroad through libel tourism US authors who mount allegations about the taint of terrorism has provoked an equally strongly hostile reaction. Perhaps because of the sensitivities of $9 / 11$, this adverse reaction has been far stronger than on previous occasions when English courts have applied libel laws more

38 S McPhilemy, The Committee: Political assassination in Northern Ireland (Lanham: Roberts Reinhart 1999).

39 McPhilemy v Times Newspapers Ltd [1999] EWCA Civ 1464, [2001] EWCA Civ 871, [2001] EWCA Civ 933.

40376 US 254 (1964).

41 S Jaschik, "A university press stands up - and wins", 16 August 2007 www.insidehighered.com/news/ 2007/08/16/yaleup. 
restrictively than the First Amendment would have allowed back home, notably in Matusevitch v Telnikoff 42 and Bachran v India Abroad Publications Inc. ${ }^{43}$

As a result, the catalogue of English libel tourism litigation is in no degree replicated on the other side of the Atlantic. Instead, a very different message is given, and it is a message which was in large part prompted by the history of Ehrenfeld in the English courts. In response to that experience, after an initial rejection by the US District Court for want of personal jurisdiction over Mahfouz, ${ }^{44}$ Ehrenfeld pursued an action for a declaratory judgment in the New York state courts to the effect that under both New York and Federal law Mahfouz could not enforce his default judgment in the US. ${ }^{45}$ The action was unsuccessful because the New York Court of Appeals decided that it could not exercise personal jurisdiction. ${ }^{46}$ Mahfouz had not invoked the privileges or protections of New York law, and the court was also not convinced by Ehrenfeld's arguments based on potential enforcement of the judgment or potential chill on her First Amendment rights. The website maintained by Mahfouz, on which he posted details of the English litigation, ${ }^{47}$ was also viewed as an insufficient jurisdictional basis for action.

This failure of Ehrenfeld in the US courts compounded the sense of disquiet on the part of First Amendment warriors whose hackles had already been raised by her defeat in the English courts. Ehrenfeld herself began instead campaigning for a legislative reaction, including later before the House of Representatives Judiciary Committee, where she did not mince her words: ${ }^{48}$

Until the New York legislature passed the Libel Terrorism Protection Act last May, I spent many sleepless nights worried that Mahfouz will try to enforce the English judgment against me in New York. His deliberate non-enforcement left it hanging over my head like a sword of Damocles, which aggravated the chilling effects.

Her efforts led to an amendment to New York's Civil Practice Act in 2008, as s. 302(d):

\section{Foreign defamation judgment.}

The courts of this state shall have personal jurisdiction over any person who obtains a judgment in a defamation proceeding outside the United States against any person who is a resident of New York or is a person or entity amenable to jurisdiction in New York who has assets in New York or may have to take actions in New York to comply with the judgment, for the purposes of rendering declaratory relief with respect to that person's liability for the judgment, and/or for the purpose of determining whether said judgment should be deemed nonrecognizable pursuant to section fifty-three hundred four of this chapter, to the fullest extent permitted by the United States constitution, provided:

42887 F Supp 1 (DDC 1995). See also Telnikoff v Matusevitch 702 A 2d 230, 251 (Md 1997): refusing to recognise the English libel judgment on public policy grounds; R B Korsower, "Matusevitch v Telnikoff: the First Amendment travels abroad preventing recognition and enforcement of a British libel judgment" (1995) 19 Maryland Journal of International Law and Trade 225.

43585 NYS 2d 661 (Sup Ct 1992); C A Stern, “Foreign judgments and the freedom of speech: look who's talking” (1994) 60 Brooklyn Law Review 999. See also Sarl Louis Feraud International v Vienfinder Inc. 489 F3d 474, 478-80 (2d Cir 2007).

44 Ehrenfeld v Mabfouz 489 F 3d 542 (2d Cir 2007): certifying question to the New York Court of Appeals.

45 Ehrenfeld v Mahfouz 872 NE 2d 866 (NY Ct App 2007).

46 Ehrenfeld v Mahfouz 881 NE 2d 830 (NY Ct App 2007).

47 www.binmahfouz.info/en_index.html.

48 Hearing on Libel Tourism before the House Subcomm. on Comm. and Admin. on the Judiciary, 111th Congress, 12 February 2009, http://judiciary.house.gov/hearings/hear_090212.html, p. 12. 
1 the publication at issue was published in New York, and

2 that resident or person amenable to jurisdiction in New York (i) has assets in New York which might be used to satisfy the foreign defamation judgment, or (ii) may have to take actions in New York to comply with the foreign defamation judgment.

The provisions of this subdivision shall apply to persons who obtained judgments in defamation proceedings outside the United States prior to and/or after the effective date of this subdivision.

Next, s. 5304(b)(8) goes on to specify that:

the cause of action resulted in a defamation judgment obtained in a jurisdiction outside the US, unless the court before which the matter is brought sitting in this state first determines that the defamation law applied in the foreign court's adjudication provided at least as much protection for freedom of speech and press in that case as would be provided by both the US and New York constitutions.

Where New York led, other states have followed. Next in the field was a 2008 Illinois statute which ensures that:

A foreign judgment is not conclusive if . . the cause of action resulted in a defamation judgment obtained in a jurisdiction outside the United States, unless a court sitting in this State first determines that the defamation law applied in the foreign jurisdiction provides at least as much protection for freedom of speech and the press as provided for by both the United States and Illinois Constitutions. ${ }^{49}$

However, Illinois has not extended its long-arm jurisdiction so as to subject foreign plaintiffs to a declaratory judgment action over claimants who have never made any attempt to enforce their foreign judgments in Illinois. Five other states have now enacted responses to Ehrenfeld's plight: Florida, ${ }^{50}$ California, ${ }^{51}$ Tennessee, ${ }^{52}$ Maryland ${ }^{53}$ and Utah. ${ }^{54}$ These have all replicated the emphasis on non-recognition and non-enforcement and have decided against providing more positive responses to libel tourism such as allowing a counter-suit going beyond declaratory relief even to the extent of awarding punitive damages. ${ }^{55}$ Though the state laws may therefore merely reinforce the states' existing public policy exceptions which effectively bar libel tourism, US comparative lawyers still debate whether the New York initiative and its progeny represents a wise development or is destined to cause a reduction in international comity as well as undue limitation of legitimate foreign private rights. ${ }^{56}$

49735 Ill Comp Stat 5/12-621(7) (2008).

50 House Bill No 949 (2009), amending Florida Statutes ss 55.605(2)(h), 55.6055.

51 Senate Bill No 320 (2009), California Statutes Chapter 579, amending ss 1716 and 1717 of the Code of Civil Procedure (2008). See A Cate, "Civil Procedure: chapter 579: the California Anti-Libel Tourism Act" (2010) 41 McGeorge Law Review 533.

52 Public Chapter no 900, House Bill No 3300, adding s. 26-6-108 (2010).

53 House Bill 193 (2010), Laws of Maryland, 2010, Chapter 658, amending Laws 6-103.3, 10-704.

54 HB 96, amending Title 78B-5-320-322, Utah Code Annotated (2010).

55 Compare the Free Speech Protection Act of 2008 - see below.

56 See J S Hemlepp, “Recent development: 'Rachel's Law' wraps New York's long-arm around libel tourists; will Congress follow suit?” (2008) 17 Journal of Transnational Law \& Policy 387; S Staveley-O'Carroll, "Libel tourism laws: spoiling the holiday and saving the First Amendment?" (2009) 4 NYU Journal of Law \& Liberty 252; M Feldman, "Putting the brakes on libel tourism: examining the effects test as a basis for personal jurisdiction under New York's Libel Terrorism Protection Act" (2010) 31 Cardozo Law Review 2457; D Rendleman, “Collecting a libel tourist's defamation judgment?" (2010) 67 Washington \& Lee Law Review 467; D C Taylor, "Libel tourism: protecting authors and preserving comity" (2010) 99 Georgia Law Journal 189. 
Moving from state level to federal interventions, Congress has passed the Securing the Protection of our Enduring and Established Constitutional Heritage Act 2010 (the SPEECH Act). ${ }^{57}$ The congressional findings bemoan the following catalogue of mischief:

(2) Some persons are obstructing the free expression rights of United States authors and publishers, and in turn chilling the first amendment to the Constitution of the United States interest of the citizenry in receiving information on matters of importance, by seeking out foreign jurisdictions that do not provide the full extent of free-speech protections to authors and publishers that are available in the United States, and suing a United States author or publisher in that foreign jurisdiction.

(3) These foreign defamation lawsuits not only suppress the free speech rights of the defendants to the suit, but inhibit other written speech that might otherwise have been written or published but for the fear of a foreign lawsuit.

(4) The threat of the libel laws of some foreign countries is so dramatic that the United Nations Human Rights Committee examined the issue and indicated that in some instances the law of libel has served to discourage critical media reporting on matters of serious public interest, adversely affecting the ability of scholars and journalists to publish their work. The advent of the internet and the international distribution of foreign media also create the danger that one country's unduly restrictive libel law will affect freedom of expression worldwide on matters of valid public interest.

(5) Governments and courts of foreign countries scattered around the world have failed to curtail this practice of permitting libel lawsuits against United States persons within their courts, and foreign libel judgments inconsistent with United States first amendment protections are increasingly common.

The core of the new protections is set out in what is now codified as 28 USC s. 4102.58

\section{Recognition of Foreign Defamation Judgments}

(a) First Amendment Considerations.-

(1) In General.-Notwithstanding any other provision of Federal or State law, a domestic court shall not recognize or enforce a foreign judgment for defamation unless the domestic court determines that-

(A) the defamation law applied in the foreign court's adjudication provided at least as much protection for freedom of speech and press in that case as would be provided by the first amendment to the Constitution of the United States and by the constitution and law of the State in which the domestic court is located; or

(B) even if the defamation law applied in the foreign court's adjudication did not provide as much protection for freedom of speech and press as the first amendment to the Constitution of the United States and the constitution and law of the State, the

57 PL 111-223, codified at 28 USC $\iint 5101-5$. This Act followed in the wake of previous attempts such as the Free Speech Protection Act of 2008 (S.2977, 110th Congress). See on that Bill, T W Moore, "Untying our hands: the case for uniform personal jurisdiction over 'Libel Tourists"' (2009) 77 Fordham Law Review 3207; E Bernstein, "Libel tourism's final boarding call" (2010) 20 Seton Hall Journal of Sports \& Entertainment Law 205; S Sturtevant, "Can the United States talk the talk and walk the walk when it comes to libel tourism: how the freedom to sue abroad can kill the freedom of speech at home" (2010) 22 Pace Intertational Law Review 269; T Zick, "Territoriality and the First Amendment: free speech at - and beyond - our borders" (2010) 85 Notre Dame Law Review 1543.

58 See E C Barbour, The SPEECH Act: The Federal Response to "Libel Tourism" R41417 (Washington DC: Congressional Research Service 2010). 
party opposing recognition or enforcement of that foreign judgment would have been found liable for defamation by a domestic court applying the first amendment to the Constitution of the United States and the constitution and law of the State in which the domestic court is located.

(2) Burden of Establishing Application of Defamation Laws.- The party seeking recognition or enforcement of the foreign judgment shall bear the burden of making the showings required under subparagraph (A) or (B).

\section{LONDON LIBEL FOG LIFTING}

This unequivocally hostile American attitude to English libel tourism litigation has been received back in England without undue rancour. Unlike some other recent legal disputes between the two jurisdictions, ${ }^{59}$ there is no threat of reaction or retaliation. This British stiff upper lip is maintained despite the perception that American legal reactions stem in part from a degree of chauvinistic sense of the superiority of First Amendment jurisprudence over English law's treatment of free expression. However, many respectable liberal democracies do not endorse the view that the protection of false speech on a US scale represents desirable public policy. ${ }^{60}$ There is also a readier perception in European jurisdictions that the mass media can be abusers of power as well as victims of power, as evidenced by ongoing and multiple scandals about phone hacking now being considered by the Leveson Inquiry into the culture, practices and ethics of the press. Nor are these more guarded opinions about rights to expression entertained only by countries with poor human rights records. They are, of course, enshrined in the balancing approach of Article 10 of the European Convention on Human Rights in which privacy interests are stronger than in US constitutional law. ${ }^{61}$ However, the English forbearance is not total, and criticism has been made of "American imperialism at its best". ${ }^{62}$ A more sustained disparagement was mounted by Lord Hoffmann in 2010:63

It is only if you think, as many Americans do, that an American should only have to say civis Americanus sum to cloak himself in the immunity of the First Amendment against liability for injury which he has caused in a foreign country, or, as much of media in this country does, that we ought to become the second country in the world to adopt the New York Times $\mathrm{v}$ Sullivan rule, that there can be any basis for criticism.

... I do not want to suggest that English libel law is perfect ... But the complaints about libel tourism come entirely from the Americans and are based upon a belief that the whole world should share their view about how to strike the balance

59 Compare the reaction to what is viewed as an imbalance in extradition laws: Police and Justice Act 2006, Sch. 13, para. 4; Guidance for Handling Criminal Cases with Concurrent Jurisdiction between the United Kingdom and the United States of America www.publications.parliament.uk/pa/ld200607/ldlwa/70125ws1.pdf.

60 For a full consideration of the respective merits of Australia, England and Wales and the US, see R L Weaver, A T Kenyon, D E Partlett, C P Walker, The Right to Speak Ill: Defamation, reputation and free speech (Durham NC: Academic Press 2006). Compare F Schauer, "Free speech in an era of terrorism: is it better to be safe than sorry?: Free speech and the precautionary principle" (2009) 36 Pepperdine Law Review 301, pp. 314-15; T S Weber, "The Free Speech Protection Act of 2009: protection against suppression" (2009/2010) 22 Regent University Law Review 481.

61 See C Walker, "European Convention" in Rogers and Milmo, Gatley, n. 17 above,.

62 Hansard HC vol. 485, col. 82WH, 17 December 2008, Andrew Pelling. See also the criticisms in the Westminster Hall debate by Edward Garnier at col. 88WH and also P Tweed, "So much for the 'special relationship"' (2009) Law Society Gazette, 23 July 2010.

63 "The libel tourism myth", Dame Ann Ebsworth Memorial Lecture, delivered on 2 February 2010 at Inner Temple www.indexoncensorship.org/2010/02/the-libel-tourism-myth/. 
between freedom of expression and the defence of reputation. And naturally the

American view is enthusiastically supported by the media in this country.

The transatlantic divergence over the suitable reactions to expressions about terrorism might further be said to be remarkable because this level of disagreement contrasts with the convergences between the jurisdiction over military interventions in "coalitions of the willing", 64 intelligence activities such as ECHELON, ${ }^{65}$ and coordinated financial listings. 66

For a variety of reasons, only some of which relate to pressures from New York, the tide is turning in English libel law towards greater hostility to libel tourism. The proposed changes are set out in the draft Defamation Bill of 2011. ${ }^{67}$ The changes of most relevance 68 are set out cl. 7 - "Action against a person not domiciled in the UK or a Member State etc":

(1) This section applies to an action for defamation against a person who is not domiciled:

(a) in the United Kingdom;

(b) in another Member State; or

(c) in a state which is for the time being a contracting party to the Lugano Convention.

(2) A court does not have jurisdiction to hear and determine an action to which this section applies unless the court is satisfied that, of all the places in which the statement complained of has been published, England and Wales is clearly the most appropriate place in which to bring an action in respect of the statement.

Libel tourism is the subject of lengthy discussion in the accompanying consultation paper and is described as being of significant concern, though certainly not on quantitative grounds. ${ }^{69}$ Clause 7 confers protection against libel tourism by ensuring that a court does not have jurisdiction to hear and determine a claim against a foreign defendant (with exceptions ${ }^{70}$ for those domiciled in the European Union $^{71}$ or in a state which is a party to

64 See R Watson, “US claims 'free hand' in its war against terror", The Times, 1 February 2002: “America will claim a free hand in taking action against states linked to terrorism regardless of international opposition,' Donald Rumsfeld, the US Defence Secretary, said yesterday. He said that Washington would accept allies into 'coalitions of the willing' as it continued its war against terrorism, but future action would not be blunted by doubters or constrained by committee."

65 See British-US Communication Intelligence Agreement 1946 (National Archives HW/80/4); European Parliament resolutions on the existence of a global system for the interception of private and commercial communications (ECHELON interception system) (2001/2098(INI)), dated 5 September 2001, and 7 November, 2002 (B5-0528/2002); M Bedan, "Echelon's effect” (2007) 59 Federal Criminal Law Journal 425.

66 UNSCR 1267 and 1373, as amended by UNSCR 1988 (2011).

67 Ministry of Justice (MoJ), Draft Defamation Bill: Consultation CP3/11 (London: TSO 2011). For previous steps in this reform history, see House of Commons Select Committee on Culture Media and Sport, Press Standards Privacy and Libel HC 362 (London: TSO 2009-10); Ministry of Justice, Report of the Libel Working Group (London: TSO 2010); (Lord Lester's) Defamation Bill 2010-2011 HL No 3 and A Mullis and A Scott, "Lord Lester's Defamation Bill 2010: a distorted view of the public interest?" (2011) 16 Communications Law 6.

68 See also cls 1 ("Substantial harm") and 2 ("Responsible journalism on matters of public interest").

69 MoJ, Draft Defamation Bill, n. 67 above, paras.79, 80. Nevertheless, the Society of Authors has described "libel tourism" as "a huge problem." JUSTICE claims it represents a serious problem for NGOs and investigative journalists, and Liberty condemns it as a "national scandal": Joint Select Committee on the Draft Defamation Bill, Written Evidence (2010-12) pp. 101, 164, 295.

70 See MoJ, Draft Defamation Bill, n. 67 above, para. 81.

71 See Council Regulation (EC) No 44/2001 of 22 December 2000 on jurisdiction and the recognition and enforcement of judgments in civil and commercial matters, as amended from time to time and as applied by the Agreement made on 19 October 2005 between the European Community and the Kingdom of Denmark on jurisdiction and the recognition and enforcement of judgments in civil and commercial matters (OJ No L229 16 November 2005, p. 62). 
the Lugano Convention) ${ }^{72}$ unless it is satisfied that, of all the potential places in which the impugned statement has been published, England and Wales is "clearly the most appropriate place in which to bring an action in respect of the statement". This holistic standard is not further explained, for example, by reference to quantity of publication, residence, or otherwise. Nor is the standard easily applied to the many global celebrities whose stardom and reputation evenly sparkle across multiple jurisdictions. ${ }^{73}$

This pending reform of the substantive law of libel is of uncertain impact because of the broad discretions embodied in these clauses. However, it seems certain that a combination of US declarations of non-enforcement (confirming the negative prognosis for recovery in any event) combined with a forthcoming legislative signal to the English judges to ask foreigners to find stronger grounds for establishing suit in London should reduce still further the rate of libel tourists wending their way to London. At the same time, given that libel tourism is factually not a common occurrence in the first place, ${ }^{74}$ and given the continued globalised nature of the media industry based in London in the second place, the impact is likely to prove marginal. Therefore, one wonders whether other reforms, such as the removal of damages as a remedy and caps on costs, ${ }^{75}$ would have made more difference to penurious authors and publishers (especially of the academic variety). Such radical changes may have to be postponed in the age of austerity when even libel courts must pursue export-driven sources of livelihood.

\section{Part 3: Lies, damned lies and the lies of libel}

First impressions from the foregoing tale of two cities - London versus New York - seem to confirm expectations. Freedom prevails in New York. It is protected by the US Constitution and jealously guarded by courts and legislatures, with recent added protection against incursions from abroad. By contrast, London welcomes the business of libel tourists to the doors of its courts, to an extent that even the government recognises to be excessive. These variant practices reflect significantly variant values as regards speech, reputation, privacy and even deference. ${ }^{76}$ Thus, on the core treatment of libel tourism and indeed of libel in general, there is no doubt that US laws set standards more favourable to publishers than English law. However, this divergence should be sustained with three reservations, two of which have already been stated in passing. One reservation is that libel tourism is not very common or effective and is likely to become less common and effective in the light of pending reforms in England and Wales. The second reservation is that the "holier than thou" attitude, as evidenced in the recitals to the congressional Bill, is rather grating. The current English position on libel is actually some way more favourable to publishers than the stance in much of Western Europe, where criminal libel remains a common hazard and is much more frequently viewed by the European Court of Human Rights as a threat to

72 See Convention on Judgments and the Recognition and Enforcement of Judgments in Civil and Commercial Matters, Between the European Community and the Republic of Ireland, the Kingdom of Norway, the Swiss Confederation and the Kingdom of Denmark signed on behalf of the European Community on 30 October 2007.

73 The Law Society has called for further clarification: Joint Select Committee, n. 69 above, p. 187.

74 In 2010, there were 3 cases out of 83 involving a foreign claimant and defendant: J Afia and P Hartley, "Tipping the balance" (2011) 161 New Law Journal 376 .

75 The financing of libel actions has been considered in: MoJ, Controlling Costs in Defamation Proceedings (London: TSO 2009); Lord Justice Jackson, Review of Civil Litigation Costs: Final Report (London: MoJ 2009), p. 319; MoJ, Proposals for Reform of Civil Litigation Funding and Costs in England and Wales (London: TSO 2010); R Shaw and P Chamberlain, "CFAs in defamation and related claims: is the gravy train coming to an end?" (2010) 15 Communications Law 51.

76 See R L Weaver et al., The Right to Speak Ill, n. 60 above, pp. $289 \mathrm{ff}$. 
freedom of expression than English libel law. ${ }^{77}$ To be less indulgent towards publishers than the US does indeed represent different value systems but to say that the English position is unconscionable is itself an extreme opinion.

A third, and larger, reservation is that this tale of the land of free speech (represented by New York) in contrast to the land of the loose writ (represented by London) becomes an even taller tall tale when a wider perspective is taken. While the US law of libel is more hostile to claimants who wish to suppress civil speech about terrorism, the favouring of speech about terrorism is not the inevitable predilection of US law. The onlooker is being misled by an undue concentration on speech affected primarily by private law interests. A rather different picture emerges when account is taken of speech affected primarily by public law interests. In many respects, US and UK public law adopt similar responses. This parity even applies to much of criminal law. For instance, while an offence such as indirect encouragement of terrorism under ss 1 and 2 of the UK's Terrorism Act 2006 might not pass muster under US constitutional standards, ${ }^{78}$ there exist several Federal offences, including "seditious conspiracy" in 18 USC s. 2384 and "material support" in 18 US Code ss $2339 \mathrm{~A}$ and $2339 \mathrm{~B}$, which have been allowed to achieve similar impact. However, in three crucial respects at least, US public law development has been more restrictive of free expression than UK equivalents. These three examples can offer a fuller sense of reality than is evident from the discussion of libel tourism alone.

The first example concerns the operation of freedom of information legislation in relation to terrorism. ${ }^{79}$ In the light of the 9/11 attacks, the Federal Attorney General, John Ashcroft, promulgated on 12 October 2001 the direction that "sensitive but not classified" information be removed from public scrutiny, resulting in the withdrawal of millions of unclassified documents (some previously released into the public domain) and the withholding of millions more documents which would have attained that status as a matter of course. 80 This initial step was followed by others relating to "critical infrastructure information" 81 and the National Security Agency. ${ }^{82}$ The Ashcroft memorandum was withdrawn on 19 March 2009, to be replaced with a version which re-established a greater degree of discretion. ${ }^{83}$

Though hardly paragons of openness, UK governments have made no comparable post-9/11 adjustments. A recent robust assertion of freedom of information was made by the Upper Tribunal (Administrative Appeals Chamber) in the All Party Parliamentary Group on Extraordinary Rendition $\mathrm{v}$ The Information Commissioner and the Ministry of Defence. ${ }^{84}$ The group's application for disclosure of any memoranda of understanding with the US regarding the potential transfer to US agencies of individuals detained by UK Forces in Iraq or Afghanistan was successful. In the view of the tribunal: ${ }^{85}$

77 See Rogers and Milmo, Gatley, n. 27 above, para. 25.13.

78 See C Walker, Terrorism and the Law (Oxford: OUP 2011), para. 8.101.

79 See 5 USC s. 552(a).

80 Memorandum from the Attorney General to the Heads of All Federal Departments and Agencies on the Subject of the Freedom of Information Act (Washington DC: 2001). See K Anderson, "Is there still a "sound legal basis?": the Freedom of Information Act in the post-9/ 11 world" (2003) 64 Ohio State Law Journal 1605; L Donohue, The Cost of Counterterrorism (Cambridge: CUP 2006) p. 342.

81 Homeland Security Act 2002 (PL no107-296) s. $211 \mathrm{ff}$.

82 National Defense Authorization Act for Fiscal Year 2004 (PL no 108-136) s. 922.

83 www.justice.gov/ag/foia-memo-march2009.pdf. This followed the Presidential Memorandum for the Heads of Executive Departments and Agencies: Freedom of Information Act, www.whitehouse.gov/the_press_office/FreedomofInformationAct/, 21 January 2009.

84 [2011] UKUT 153 (AAC).

85 Ibid. paras 59, 64. 
We very much doubt that the terms of a memorandum of understanding or similar agreement that is designed to ensure compliance with human rights and similar legal obligations in respect of people whose detention is transferred to another state could be perceived as confidential in nature or something the existence of which embarrasses foreign states ...

Since the maintenance of the rule of law and protection of fundamental rights is known to be a core value of the government of the United Kingdom, it is difficult to see how any responsible government with whom we have friendly relations could take offence at open disclosure of the terms of an agreement or similar practical arrangements to ensure that the law is upheld.

Furthermore, the British media has been subjected to fewer official threats and explicit restrictions than applied in the era of Irish Republican terrorism. ${ }^{86}$

A second instructive contrast relates to the impact of claims to state secrecy in litigation about terrorism. Here again, the English courts have often demanded greater disclosure from the state than has been the US practice. A relatively direct comparison may be garnered from the litigation of Binyam Mohamed. Binyam Mohamed is an Ethiopian national who had been resident in London from 1994 until 2001, when he travelled to Afghanistan. He was arrested at Karachi airport in April 2002 while attempting to return to the UK, following which he was allegedly imprisoned in Pakistan, Morocco (where he alleged that torture took place) and Afghanistan, the transportation being arranged under the US extraordinary rendition program. He was then taken from Bagram airbase to Guantánamo Bay on 19 September 2004 and was charged before the military tribunal with conspiracy offences in 2005 (which were replaced with new charges in 2008). However, the charges were dropped, and he was returned to the UK on 23 February 2009.

As far as his English litigation is concerned, Binyam Mohamed has sought discovery concerning his treatment in Pakistan and Morocco so as to defend military commission proceedings (which were in fact dropped in 2009 when he was released from Guantánamo but without prejudice to future charges). ${ }^{87}$ Seven former detainees (including Binyam Mohamed) are also seeking civil damages for British complicity in their detention at Guantánamo. ${ }^{88}$ Some of the documentation in the hands of the British government originated from US agencies who had transmitted on a strict policy of no further disclosure - the "control principle". The High Court adopted a balancing exercise between the public interests in disclosure versus national security and healthy international relations, as well as alternative means to disclosure (such as an inquiry by the Intelligence and Security Committee). ${ }^{89}$ The High Court ordered disclosure, judging that the US threats to withhold security cooperation were empty. The Court of Appeal endorsed this assessment, relying on the further factor that a US Federal Court had already granted disclosure to the claimant, and it also rejected that the "control principle" was an immutable legal requirement. ${ }^{90}$ The judgment was also notable for the comment by Lord Neuberger MR that "some SyS officials appear to have a dubious record when it comes to human rights and coercive techniques, and indeed when it comes to frankness about the UK's

86 See Walker, Terrorism, n. 78 above, para. 8.104.

87 Mohamed v Secretary of State for the Foreign and Commonwealth Office [2008] EWHC 2048, 2100, 2159 (Admin), [2009] EWHC 152, 2048, 2549, 2973 (Admin), [2010] EWCA Civ 65, 158. See also R (Aamer) v Secretary of State for the Foreign and Commonwealth Office [2009] EWHC 3316 (Admin).

88 See Al-Rawi v Security Service [2011] UKSC 34: the Supreme Court rejected the government's demand for a closed material procedure in a civil claim for damages.

89 See The Handling of Detainees by UK Intelligence Personnel in Afghanistan, Guantánamo Bay and Iraq Cm 6469 (London: 2005).

90 [2010] EWCA Civ 65. 
involvement with the mistreatment of Mr Mohammed by US officials". 91 Police and judicial inquiries have flowed from this litigation, as well as a Green Paper, ${ }^{92}$ plus potential governmental demands for special rules to nullify any "quixotic" judge who creates a "material risk" to security. 93

These allegations, even though they are yet to be proven or resolved, have caused considerable official consternation. The assessment of the Intelligence and Security Committee is that the UK authorities were slow to appreciate the changed practices around extraordinary rendition beyond criminal justice of the US authorities and that guidelines as to involvement were not adequate. ${ }^{94}$ The All Party Parliamentary Group on Extraordinary Rendition has called for criminal law prohibitions of facilitation or the use of facilities. ${ }^{95}$ Though connivance in torture is denied, ${ }^{96}$ the civil claims have been settled, ${ }^{97}$ and a judicial inquiry (under Sir Peter Gibson) was announced in 2010.98 The government has also published the Consolidated Guidance to Intelligence Officers and Service Personnel on the Detention and Interviewing of Detainees Overseas, and on the Passing and Receipt of Intelligence Relating to Detainees. A system of reference up to a minister applies whenever risk of serious abuse is present. ${ }^{99}$

A less wholesome picture emerges in the counterpart US civil processes. State secrets privilege ${ }^{100}$ has been increasingly invoked to exclude evidence based on an affidavit by the government and without any closed hearing or examination by the court. The US-based civil claims of Binyam Mohammed and others against Jeppesen Dataplan, an air carrier acting on behalf of the CIA, were halted because of state secrets privilege. ${ }^{101}$ The doctrine was also invoked to prevent the civil action of Khalid el-Masri, a German citizen who was allegedly rendered from Macedonia to Afghanistan in 2003. ${ }^{102}$ Likewise, the civil claims of Maher Arar, a Canadian citizen who was detained in New York and sent to Syria whilst en route to Canada, ${ }^{103}$ were rejected in Arar v Ashcroft, though on other grounds. ${ }^{104}$

The third and final example of differential approaches to public law boundary-setting to discussion of terrorism concerns the disclosure of information by WikiLeaks. Official approaches have been markedly different to the publication in late 2010 and onwards via

91 [2010] EWCA Civ 158, para. 17.

92 See Ministry of Justice, Security and Justice Cm 8194 (London: 2011).

93 Privy Council Review of intercept as evidence, Report to the Prime Minister and the Home Secretary Cm 7324 (London: 2008), paras. 63, 90.

94 Rendition Cm 7171 (London 2007), para. 77. See also The Handling of Detainees, n. 89 above.

95 Extraordinary Rendition: Closing the gap (London: 2009). See also Joint Committee on Human Rights, Allegations of UK Complicity in Torture HL 152/HC 230 (2008-2009) and Government Reply Cm 7714 (London: 2009).

96 The Times, 29 October 2010, p.1 6 (Sir John Sawers).

97 Hansard HC vol. 518, col. 752, 16 November 2010, (Kenneth Clarke).

98 Hansard HC vol. 513, col. 175, 6 July 2010 (David Cameron).

99 Consolidated Guidance to Intelligence Officers and Service Personnel on the Detention and Interviewing of Detainees Overseas, and on the Passing and Receipt of Intelligence Relating to Detainees and Note of Additional Information (London: Cabinet Office 2010).

100 US v Reynolds (1953) 345 US 1.

101614 F 3d 1070 (2010).

102 El-Masri v Tenet (2006) 437 F Supp 2d 530, (2007) 479 F 3d 296 (cert den 169 L Ed 2d 258; 2007). See R M Chesney, "State secrets and the limits of national security litigation" (2007) 75 George Washington Law Review 1249; S Townley, "The use and misuse of secret evidence in immigration cases: a comparative study of the United States, Canada, and the United Kingdom" (2007) 32 Yale Journal of International Law 219; L Donohue, "The shadow of state secrets" (2010) 159 University of Pennsylvania Law Review 77.

103 See Commission of Inquiry into the Actions of Canadian Officials in relation to Maher Arar (Ottawa: 2007). 104 (2008) 532 F 3d 157. See E Craddock, “Tortuous consequences and the case of Maher Arar" (2008) 93 Cornell Law Review 621. 
WikiLeaks of over 250,000 US embassy diplomatic cables. Many of the most publicised have related to terrorism issues, such as the Lockerbie bombing ${ }^{105}$ or Guantánamo detainees. ${ }^{106}$ The head of WikiLeaks, Julian Assange, is subject in the UK to extradition procedures for sex offences in Sweden, ${ }^{107}$ an application which is being resisted in part because of the fear of onward rendition to the US. However, as for the publications themselves, a rather phlegmatic attitude has mainly been maintained by members of the UK government without any attempt to stop the flow of information or to initiate rhetoric about any threat of prosecution for the expression, as illustrated by the following two sets of Parliamentary exchanges: 108

Joseph Johnson: Will the Minister give an assessment of the impact of the WikiLeaks affair on the conduct of diplomacy, and will he say what steps he plans to take, on the one hand, to tighten access to diplomatic cables that need protecting and, on the other hand, to free up access to the other information that can and should be in the public domain? The latter would also enhance the Government's transparency agenda.

The Minister of State, Foreign and Commonwealth Office (Mr Jeremy Browne): We believe in freedom of information and open and transparent government, but there is a private realm and a legitimate area for confidentiality in diplomatic relations between nations. We need to get that balance right to ensure that we are secure when trying to safeguard confidential information. That is what we are working to do.

Simon Kirby: To ask the Secretary of State for Foreign and Commonwealth Affairs what discussions he has had with the US administration on the disclosure of classified material by Wikileaks.

Alistair Burt: My right hon. Friend the Foreign Secretary spoke to Secretary Clinton on 26 November 2010 about a range of issues including Wikileaks.

By contrast, the US Secretary of State, Hillary Clinton, has generated a livid reaction to WikiLeaks, describing the revelation of the diplomatic cables as tearing at "the fabric of the proper function of government."109 Congressional speakers have even called for a prosecution for treason. ${ }^{110}$ The Espionage Act 1917111 appears to be a more workable option, though, to bolster its chances of success, an amendment has been proposed in Congress by way of the Securing Human Intelligence and Enforcing Lawful Dissemination (SHIELD) Act. ${ }^{112}$ The source of the leaks, Bradley Manning, a former US Army intelligence analyst, has not only been arrested but has been subjected to extraordinarily degrading conditions of confinement which have themselves become a subject of

105 See 08LONDON2673, Pan Am 103 bomber has incurable cancer, http://wikileaks.dp.ru/cable/2008/10/ 08LONDON2673.html.

106 See http://wikileaks.ch/gitmo/.

107 Assange v Swedish Prosecution Authority [2011] EWHC 2849 (Admin) (appeal to the Supreme Court pending).

108 Hansard HL vol. 520, col. 795, 14 December 2010; Hansard HC vol. 520, col. 478W, 13 December 2010. David Cameron's spokesman said that "The leaks and their publication are damaging to national security in the United States and in Britain and elsewhere.", The Times, 30 November 2010, p. 2.

109 G Whittell, "Clinton condemns 'sabotage' amid frantic efforts to keep allies onside", The Times, 30 November 2010, pp. 4, 5. See further K Kovarovic, "When the nation springs a (wiki)leak" (2011) 14 Tuoro International Law Review 273.

110 Congressional Record: 30 November 2010, House of Representatives, p. H7744, Steve King (R-IA).

11118 USC s. $792 \mathrm{ff}$.

112 111th Congress 2d Sess HR 6506, S 4004. See G R Stone, "WikiLeaks, the proposed SHIELD Act and the First Amendment” (2011) 5 Journal of National Security Law \& Policy 105. 
controversy 113 and the application of which merely serves to underline the vehemence with which the US authorities are seeking to condemn publication. Defenders of these US reactions draw a comparison with the case of the Pentagon Papers - the secret report on United State-Vietnam Relations, 1945-1967: A Study which was prepared for the Department of Defense and leaked by the New York Times. The proponents of US law can rightly emphasise that, despite any political rhetoric, the First Amendment provides a strong bulwark against prior restraint, as availed the New York Times when faced with a government-requested injunction. ${ }^{114}$ Yet, this fine affirmation of press freedom represented by the Pentagon Papers case, with the New York Times as the lead beneficiary, may not necessarily be replicated for a non-press source like WikiLeaks, though the fact that it is the publisher rather than the originator of the disclosure may assist in its protection. ${ }^{115}$ The fate of the New York Times must in any event be set alongside the determination to prosecute subsequently the sources of the leak, Daniel Ellsberg and his colleague Anthony Russo. They were discharged in 1973 from charges under the Espionage Act 1917,116 which carried a potential penalty of 115 years, but only through the chance revelation that the investigation had been tainted by unconstitutional "covert operations". 117

In the light of these three contrasts, the initial tale of two cities - one which related the starkly contrasting fate of free speech - becomes a tall tale or at least a much murkier yarn. While English law is certainly more attuned to private interests via libel law, it is US public law which often seems readier to suppress public speech. Terrorism may again provide the recurrent linking and explanatory theme in this story. In other words, just as global terrorism has been the frequent subject of global civil "libel tourism", so the greater shock of terrorism to the US polity than to European states and populations inured to terrorism over three decades perhaps explains why US public laws have now turned very hostile to freedoms, including freedoms relating to speech, when security against terrorism seems to be at stake. As a result, the US is too readily depicted as a paragon of virtue because of its constitutional priority for expressive rights over private interests. The UK jurisdiction appears readier to admit inquiry and criticism in the public sphere, a stance which is ultimately far more important to the health of society than the US habit of overriding the sensitivities of a few wealthy litigants. Accordingly, the litigation by Binyam Mohamed has done far more to expose and shape public policy, say on torture, than have books by Ehrenfeld and others. Indeed, despite her published allegations, the US state remains markedly reticent about allowing further inquiry into the financing of terrorism by its allies and their citizens, especially in Saudi Arabia. In conclusion, it would be better for all governments to be more open and honest in their public speech than to peddle tall tales about the damage to private speech from shortcomings in the libel laws of their neighbours.

113 See R Cornwell, "A new jail for Bradley Manning - but the controversy rages on", The Independent, 21 April 2011, p. 25.

114 New York Times Co. v US 403 US 713 (USSC, 1971). For exceptions, see US v Progressive Inc. 467 F Supp 990 (WD Wis 1979); US v Austin (CR02-884SVW, CD Cal, 2004). The Pentagon Papers were published in full in June 2011: www.archives.gov/research/pentagon-papers.

115 See Bartnikiv Vopper 532 US 514 (USSC, 2001).

11618 USC ss. 793(e) and 641.

117 See In re Ellsberg 446 F2d 954 (1st Cir 1971); Ellsberg v Mitchell 353 F Supp 515 (DDC, 1973); Ellsberg v Mitchell 670 F Supp 1 (DDC, 1984); D Ellsberg, Secrets: A memoir of Vietnam and the Pentagon Papers (New York: Viking Press 2002). 